Review

\title{
Adipogenic Transcriptome Profiling Using High Throughput Technologies
}

\author{
Urmila Basu, Josue Moura Romao, Le Luo Guan ${ }^{\bowtie}$ \\ Department of Agricultural, Food and Nutritional Science, University of Alberta, Edmonton, Alberta, Canada
}

\begin{abstract}
$\triangle$ Corresponding author: Leluo Guan. 318E Agriculture/Forestry Centre, Department of Agricultural, Food and Nutritional Science, University of Alberta, Edmonton, AB, Canada, T6G 2P5. Tel: +1 780-492-2480, Fax: +1-780-4924265, E-mail: lguan@ualberta.ca
\end{abstract}

( ) Ivyspring International Publisher. This is an open-access article distributed under the terms of the Creative Commons License (http://creativecommons.org/ licenses/by-nc-nd/3.0/). Reproduction is permitted for personal, noncommercial use, provided that the article is in whole, unmodified, and properly cited.

Published: 2013.11 .01

\begin{abstract}
The recent technological innovations in the area of functional genomics, gene expression/transcriptomic profiling can provide new insights to understand the molecular basis of adipogenesis. The focus of this review is to highlight the recent advances in our understanding of the complex interplay of gene expression events and the regulatory mechanisms of adipogenesis in mouse cell lines, humans and farm animals. All these studies have employed the availability of constantly evolving high throughput 'omics' technologies including microarrays, RNA-Seq, chromatin immunoprecipitation, next generation sequencing, RNAi, miRNA profiling and quantitative PCR arrays.
\end{abstract}

Key words: transcriptome, adipogenesis, functional genomics, gene expression

\section{Introduction}

Adipogenesis is the process by which immature adipose cells differentiate into specialized mature cells, such as adipocytes, being able to synthesize and store fatty acids in the form of triglycerides as well as to release free fatty acids, playing an important role in the energy regulation [1]. Not only the adipose cells store and release fatty acids, but they also release a series of adipokines that have various regulatory functions on energy metabolism, such as leptin, that inhibits the food intake and stimulate energy expenditure [2]. Another aspect that has gathered the attention of researchers to adipose tissue is the significant increase of obesity in humans which is a critical risk for human health, especially in developed countries [2]. Obesity is now a major concern for not only humans but also for companion animals' health, such as dogs and cats which are more and more affected by this condition [3]. Besides health aspects, the adipose tissue has also been studied in the farm animals, especially those specialized in meat production such as: beef cattle, pigs and broilers. The reason is that adi- pose tissue is an important characteristic related to meat quality and nutritional value of the meat and can also impact animal productivity $[4,5]$. However, our understanding of the regulatory mechanisms on adipogenesis in mammalian species is currently very limited.

Studies in the past decades on the molecular mechanism of adipogenesis have revealed the important role that this tissue plays in the regulation of fat and energy metabolism [6]. Recent studies have also indicated the importance of adipogenic transcription factors such as Peroxisome Proliferator Activated Receptor $\gamma($ PPAR $\gamma)$, CCAAT-Enhancer Binding Proteins (C/EBPs), Kruppel Like Factors (KLFs) and Sterol Regulatory Element Binding Protein (SREBP), in regulating the expression of many adipogenic genes leading to the differentiation of adipocytes $[7,8]$. Besides the transcriptional factor regulated mechanisms, many other genes have been also reported to be differentially expressed during adipogenesis, suggesting that the adipogenesis is a complex 
process associated with many regulatory mechanisms. In this paper, we have focused on elucidation of molecular mechanisms of adipogenesis by studying the transcriptome (mRNAs and miRNAs) using advanced high throughput technologies. Recently, high-throughput technologies have become essential tools for large scale studies for identification of the molecular networks associated with adipogenesis. These include microarrays or RNA-Seq for gene expression profiling, chromatin immunoprecipitation followed by microarray analysis (ChIP-chip), or next generation sequencing (ChIP-Seq) for comprehensive analysis of target genes of transcription factors, RNAi screening in conjunction with microarray, DNase I hypersensitivity analysis, and adipogenesis quantitative PCR array [9-11].

\section{Microarrays/Quantitative real time PCR/Adipogenesis real time PCR array}

DNA microarrays comprising hundreds or thousands of DNA fragments arrayed on small glass slides which can be used to probe the entire tran- scriptome to give an overall picture of gene expression behavior [12]. Quantitative real-time PCR (qRT-PCR) combines the amplification of a DNA sequence with the detection of the amplified products during each reaction cycle and is a commonly used validation tool for confirming gene expression results obtained from microarray analysis [13]. Microarray technology has been used in several gene expression profiling studies (see Table 1 for some examples) in cell culture models from mouse pre-adipocyte cell line 3T3-L1 [14-18], human mesenchymal stem cells or subcutaneous abdominal fat sample [19-23], bovine [24-27], pig [28-30] as well as other organisms [31] to monitor transcriptional changes associated with adipogenesis. Different array technologies including commercially available Genome Arrays (Affymetrix), custom spotted oligonucleotide or cDNA arrays [10] have been employed in conjunction with qRT-PCR for most of these studies to identify molecular changes at different stages of adipogenesis in response to different treatments for differentiation [10, 17, 32, 33].

Table I: List of major adipogenic candidates identified in mouse cell line, human, bovine and porcine by gene expression profiling using microarray.

\begin{tabular}{|c|c|c|c|}
\hline Organism & Microarray used & Major candidate genes & Reference \\
\hline \multirow[t]{6}{*}{$\begin{array}{l}\text { Mouse cell } \\
\text { line (3T3-L1) }\end{array}$} & $\begin{array}{l}\text { Mouse genome array (Affymet- } \\
\text { rix) }\end{array}$ & Liver $X$ receptor a $(L X R a)$ & $\begin{array}{l}\text { Ross et al., } 2002 \\
{[14]}\end{array}$ \\
\hline & $\begin{array}{l}\text { Mouse genome array (Affymet- } \\
\text { rix) }\end{array}$ & $\begin{array}{l}\text { Transcriptional enhancer and activator domain }(T E A D) \text {; Latex- } \\
\text { in gene; Thymus Inhibitor of Apoptosis (TIAP) } \\
\text { Tolloid-like mRNA ( } m \text { Tld }) \\
\text { Disintegrin and metalloprotease domain-8 (ADAM 8); Myelin basic } \\
\text { protein expression factor } 2 \text { (MYEF 2) }\end{array}$ & $\begin{array}{l}\text { Burton et al., } \\
2004[15]\end{array}$ \\
\hline & $\begin{array}{l}\text { Mouse genome array (Affymet- } \\
\text { rix) }\end{array}$ & Integrins a5 and a 6 & $\begin{array}{l}\text { Liu et al., } 2005 \\
{[16]}\end{array}$ \\
\hline & $\begin{array}{l}\text { 38K Mouse Exonic Evi- } \\
\text { dence-based Oligonucleotide } \\
\text { (MEEBO) microarray }\end{array}$ & $\begin{array}{l}\text { CCAAT-enhancer-binding proteins }(C / E B P S) \\
\text { Peroxisome proliferator activated receptor } y^{\prime}(P P A R \gamma)\end{array}$ & $\begin{array}{l}\text { Pantoja et al., } \\
2005[17]\end{array}$ \\
\hline & $\begin{array}{l}\text { Affymetrix mouse array and } \\
\text { RNA interference (RNAi) }\end{array}$ & $\begin{array}{l}\text { Receptor interacting protein } 140 \text { (RIP140); } \\
\text { Mitogen-activated protein kinase (MAP4k4); Fat specific protein } 27 \\
\text { (FSP27) }\end{array}$ & $\begin{array}{l}\text { Puri et al., } 2008 \\
{[38]}\end{array}$ \\
\hline & Affymetrix mouse array & $\begin{array}{l}\text { SIRT1-related transcriptional signature; } \\
\text { A transcription factor (TCF21) }\end{array}$ & $\begin{array}{l}\text { Timmons et al., } \\
2007[32]\end{array}$ \\
\hline $\begin{array}{l}\text { Mouse em- } \\
\text { bryonic stem } \\
\text { cells }\end{array}$ & Affymetrix mouse array & $\begin{array}{l}500 \text { differentially expressed (DE) genes - PPARy; Fatty acid bind- } \\
\text { ing protein } 4 \text { (FABP4); Forkhead boc C } 2 \text { (FOXC2); CCAAT en- } \\
\text { hancer-binding protein }\end{array}$ & $\begin{array}{l}\text { Billon et al., } \\
2010[37]\end{array}$ \\
\hline \multirow[t]{5}{*}{ Human } & cDNA microarray (3400 genes) & 197 DE genes & $\begin{array}{l}\text { Nakamura et } \\
\text { al., } 2003 \text { [19] }\end{array}$ \\
\hline & microarray & $\begin{array}{l}113 \text { DE genes- } P P A R r 2 \text {, lipoprotein lipase }(L P L) \text {, and fatty acid } \\
\text { binding protein }(F A P 2)\end{array}$ & $\begin{array}{l}\text { Hung et al., } \\
2004[20]\end{array}$ \\
\hline & microarray & $\begin{array}{l}67 \text { DE genes - } P P A R r ; \text { CCAAT enhancer-binding protein alpha; } \\
\text { acylCoA synthetase, lipoprotein lipase }(L P L) ; F A B P 4\end{array}$ & $\begin{array}{l}\text { Sekiya et al., } \\
2004[21]\end{array}$ \\
\hline & microarray & $\begin{array}{l}1606 \text { DE genes- Liver x-receptor }(L X R a) \text {; COUP transcription factor } \\
1 \text { (COUP-TF1); phospholipid transfer protein }(P L T P) \text {, and the } \\
\text { transmembrane protein (TMEM135) }\end{array}$ & $\begin{array}{l}\text { Scheideler et al., } \\
2008 \text { [22] }\end{array}$ \\
\hline & cDNA microarray & $\begin{array}{l}\text { CCAAT enhancer-binding protein alpha; PPARr; Angiopoiet- } \\
\text { in-like } 4 \text { (ANGPTL4) }\end{array}$ & $\begin{array}{l}\text { Rodri- } \\
\text { guez-Acebes et } \\
\text { al., } 2010[23]\end{array}$ \\
\hline
\end{tabular}




\begin{tabular}{|c|c|c|c|}
\hline \multirow[t]{3}{*}{ Cattle } & Bovine genome microarray & 158 DE genes- FABP4 & $\begin{array}{l}\text { Tan et al., } 2006 \\
{[24]}\end{array}$ \\
\hline & Bovine genome microarray & $\begin{array}{l}100 \text { DE genes- PPAR } \gamma ; \text { sterol regulatory element binding protein } 1 \\
(S R E B P-1)\end{array}$ & $\begin{array}{l}\text { Taniguchi et al., } \\
2008 \mathrm{a}, 2008 \mathrm{~b} \\
{[25,26]}\end{array}$ \\
\hline & Bovine genome microarray & $\begin{array}{l}\text { Disintegrin and metalloproteinase with thrombospondin motifs } 4 \\
\text { (ADAMTS4) }\end{array}$ & $\begin{array}{l}\text { Lee et al., } 2010 \\
\text { [27] }\end{array}$ \\
\hline \multirow[t]{2}{*}{ Pig } & $\begin{array}{l}\text { cDNA microarray with } 3500 \\
\text { genes }\end{array}$ & $\begin{array}{l}81 \text { DE genes- FABP (aP2), stearvl-CoA desaturase (SCD), sterol } \\
\text { regulatory element binding transcription factor } 1(S R E B F 1) \text { and } \\
\text { lipoprotein lipase }(L P L)\end{array}$ & $\begin{array}{l}\text { Guo et al., } 2008 \\
\text { [28] }\end{array}$ \\
\hline & $\begin{array}{l}\text { Porcine Genome Array (Affy- } \\
\text { metrix) }\end{array}$ & $\begin{array}{l}5066 \text { DE genes - Fattv acid svnthase (FASN); LPL; } \\
\text { 3-beta-hydroxvsteroid dehvdrogenase/delta-5-delta-4 isomerase } \\
\text { (HSD3B1); angiopoietin-like-4 (ANGPTL4); uncoupling protein } 3 \\
\text { (UCP3) }\end{array}$ & $\begin{array}{l}\text { Barb et al., } 2010 \\
\text { [29] }\end{array}$ \\
\hline
\end{tabular}

A large number of genes identified by these microarray studies, using different cell models or organisms, are found to be associated with adipocyte differentiation which is driven by a network of transcriptional regulators [10,34]. Some of these examples include members of Kruppel-like factor (Klf4) family, Klf6 and Klf5, which are required for adipogenesis by transactivating PPARY [35]; and zinc finger containing transcription factor Egr2 (Krox2), which stimulates adipogenesis through activating $C / E B P-\beta$ by binding to its promoter [36]. Besides these, genes encoding a number of enzymes including xanthine dehydrogenase (Xdh, XOR), stearoyl-CoA desaturase (Scd1), adipose triglyceride lipase Pnpla2 (ATGL) have also been identified through these microarray studies [34]. Genome wide microarray analysis in Hanwoo (Korean cattle) identified a disintegrin and metalloproteinase with thrombospondin motifs 4 as one of the key genes controlling the relationship between marbling fat deposition and connective tissue degradation [27].

Several transcription factors and motifs with no previous link to adipocyte biology were identified using genome-wide analysis of gene expression during adipogenesis of mouse embryonic stem cells. This study utilized Mouse Genome array (Affymetrix), qRT-PCR and in silico prediction analysis of transcription factor binding sites with comprehensive bioinformatics analysis [37]. Puri et al. [38] identified the role of Receptor interacting protein 140 and Mitogen-activated protein kinase as powerful regulators of adipogenesis by performing Mouse Genome array (Affymetrix) comparative gene expression profiling of siRNA knock out cultured 3T3-L1 adipocytes cells vs. control. However, inconsistencies have been observed in some of these microarray studies due to the usage of different platforms and protocols, probe sequences or their annotations. Recently available, "Adipogenesis Pathways ${ }^{\mathrm{TM}}$ Focused Human Genome Microarrays" (ArrayIt Corporation) which contain long-mer capture agents for 89 genes involved in the human adipogenesis pathway, would provide a solution to overcome these inconsistencies in the human adipogenesis studies. Furthermore, the mouse adipogenesis RT Profiler PCR array (QIAGEN) can also be utilized to analyze the gene expression of a focused panel of 84 key genes involved in adipogenesis, with real time PCR sensitivity and the multi-gene profiling capability of a microarray.

\section{Next generation sequencing/Chromatin im- munopreciptation (ChIP)-chip / ChIp-Seq}

Next-generation sequencing (NGS) technologies, which are able to simultaneously sequence several thousand DNA fragments, including whole-transcriptome sequencing using RNA sequencing (RNA-Seq) or digital gene expression (DGE) profiling, have started to reveal the complexities of different biological processes at an unprecedented level of sensitivity and accuracy [39-41]. Table 2 lists examples of the adipogenesis studies conducted in different organisms using high throughput technologies. Differential gene expression during adipogenesis in a clonal bovine intramuscular preadipocyte cell line using serial analysis of gene expression identified 878 differentially expressed genes [42]. Digital gene expression-tag profiling was performed to generate transcriptome profiles of backfat tissues from beef steers to elucidate the molecular mechanism of fat deposition in adipose tissues [43]. In this study [43], a total of 18,034 genes were identified and 650 genes were found to be differentially expressed including Retinoblastoma 1, PPARa, Stearoyl-CoA desaturase 5, ATP citrate lyase, Leptin, phosphate cytidylyltransferase 2 ethanolamine, Interleukin 18, and Serpin peptidase inhibitor, clade E, member 1 . Recently, Chen et al. [44] used high throughput RNA-Seq to generate a high-resolution map of the porcine mRNA and miRNA transcriptome in liver, muscle and fat from a full-sib F2 female pair with extreme phenotypes. This study provided not only provided a global view of the pig transcriptome but also revealed new information 
about the large scale alternative splicing events and identified gene boundaries at single nucleotide resolution. A high degree of transcriptional complexity in the regulatory mechanisms of adipogenesis in porcine adipose tissue was revealed by the identification of 1596 differentially expressed genes [45].

Chromatin immunopreciptation (ChIP) is widely used for identifying and characterizing elements like histones, transcriptional factors, in protein-DNA interactions involved in the gene regulation or chromatin organization [46]. ChIP-chip (chromatin immunoprecipitation-on-chip) involves incubation of the genomic DNA in the presence of proteins, shearing of DNA into small pieces followed by the immunoprecipitation of DNA-bound proteins with an antibody. Subsequently, DNA is purified, labeled and hybridized to microarray which allows identification of significantly enriched sequences bound by the proteins of interest [47]. Most of the changes occurring dur- ing adipogenesis are thought to be controlled or mediated by particular transcription factors and ChIP-chip is able to produce comprehensive genome-wide location information for specific transcription factors. Several target genes of PPARy were identified using integrated analyses of ChIP-chip, expression microarray and computational motif search [9]. Other studies have characterized PPARY and C/EBPa-binding sites in mature 3T3-L1 adipocytes using ChIP-chip [48]. Although microarray platforms provide a method for 'global' ChIP analysis, a novel approach combining Chip assay with next generation parallel sequencing (ChIP-Seq) has allowed researchers to study genome-wide protein DNA interactions in an unbiased manner [47, 49]. These genome-wide studies employing ChIP-Seq have improved our understanding of the transcriptional networks controlling adipogenesis at different stages of differentiation [50-52].

Table 2: High throughput technologies to identify candidate adipogenic genes, transcription factors (TFs), and chromatin region in mouse cell line, human, bovine and porcine

\begin{tabular}{|c|c|c|c|}
\hline Organism & Technology used & Candidate genes / TFs / chromatin regions & Reference \\
\hline \multirow[t]{8}{*}{$\begin{array}{l}\text { Mouse cell } \\
\text { line (3T3-L1) }\end{array}$} & ChIP-chip & $\begin{array}{l}\text { Transmembrane protein } 143 \text { (TMEM143); } \\
\text { Haptoglobin (HP); Fatty acid binding protein } 4 \text { (FABP4); Adipsin (CFD) }\end{array}$ & $\begin{array}{l}\text { Nakachi et al., } \\
2008[9]\end{array}$ \\
\hline & $\begin{array}{l}\mathrm{ChIP} / \text { whole genome } \\
\text { tilling arrays }\end{array}$ & 5299 genomic regions of $P P A R \gamma$ binding & $\begin{array}{l}\text { Lefterova et al., } \\
2008[48]\end{array}$ \\
\hline & ChIP-Seq & $\begin{array}{l}\text { Genome wide map of }>5000 P P A R \gamma \text { and retinoid } X \text { receptor }(R X R) \text {-binding } \\
\text { sites }\end{array}$ & $\begin{array}{l}\text { Nielsen et al., } \\
2008[50]\end{array}$ \\
\hline & $\begin{array}{l}\text { ChIP-PET (ChiP pair } \\
\text { end-tagging technology) }\end{array}$ & 7700 DNA binding sites of $P P A R \gamma$ and $R X R$ & $\begin{array}{l}\text { Hamza et al., } \\
2009[51]\end{array}$ \\
\hline & ChIP-chip and ChIP-Seq & $\begin{array}{l}\text { Histone H4 Lvs } 20 \text { (H4K20) - transcriptional regulation and epigenetic } \\
\text { chromatin modulation }\end{array}$ & $\begin{array}{l}\text { Wakabayashi et } \\
\text { al., 2009 [53] }\end{array}$ \\
\hline & ChIP-Seq & $\begin{array}{l}\text { Co-localization of PPAR } r \text { with the hematopoietic transcription factor PU.1 } \\
\text { in areas of open chromatin and histone acetylation }\end{array}$ & $\begin{array}{l}\text { Lefterova et al., } \\
2010[54]\end{array}$ \\
\hline & $\begin{array}{l}\text { Illumina's Mouse Ref- } 8 \\
\text { Expression BeadChips }\end{array}$ & ETS (E-twenty six) family transcription factor & $\begin{array}{l}\text { Birsoy et al., } \\
2011[18]\end{array}$ \\
\hline & $\begin{array}{l}\text { Genome-wide mapping } \\
\text { of DNase-hypersensitive } \\
\text { regions using DHS-Seq }\end{array}$ & $\begin{array}{l}\text { Multiple transcription factor 'hotspots' } P P A R \gamma ; C / E B P a \text {; glucocorticoid } \\
\text { receptor, retinoid X receptor }\end{array}$ & $\begin{array}{l}\text { Siersbaek et al., } \\
2011[59]\end{array}$ \\
\hline \multirow[t]{2}{*}{ Human } & $\begin{array}{l}\text { ChIP-Seq in mature } \\
\text { human SGBS adipocytes }\end{array}$ & 52,733 C/EBPa and 23,328 PPAR $\gamma$ binding sites & $\begin{array}{l}\text { Schmidt et al., } \\
2011[56]\end{array}$ \\
\hline & ChIP-Seq & $\begin{array}{l}\text { Histone } \mathrm{H} 3 \text { on Lysine } 56 \text { (H3K56) acetylation, E2F4 recognition, C/EBPa } \\
\text { and HSF-1 binding }\end{array}$ & $\begin{array}{l}\text { Lo et al., } 2011 \\
{[58]}\end{array}$ \\
\hline \multirow[t]{2}{*}{ Cattle } & $\begin{array}{l}\text { Serial analysis of gene } \\
\text { expression (SAGE) }\end{array}$ & $\begin{array}{l}878 \text { DE genes - Collagen Tvpe } 1 \text { (COL18A1); Glutathione peroxidase } \\
\text { (GPX3); Serum amvloid A3 (SAA3); Fibronectin } 1 \text { (FN1); Adipose differ- } \\
\text { entiation-related protein }(A D F P)\end{array}$ & $\begin{array}{l}\text { Mizoguchi et } \\
\text { al., } 2010[42]\end{array}$ \\
\hline & $\begin{array}{l}3 \text { ' digital gene expres- } \\
\text { sion tag profiling }\end{array}$ & $\begin{array}{l}650 \text { DE genes - Retinoblastoma 1(RB1); PPARa; Stearovl-CoA desaturase } 5 \\
\text { (SCD5); ATP citrate lvase (ACLY); Leptin (LEP); phosphate cvtidvl- } \\
\text { vltransferase } 2 \text { ethanolamine (PCYT2); Interleukin } 18 \text { (IL18); Serpin pepti- } \\
\text { dase inhibitor, clade E, member } 1(\text { SERPINE1) }\end{array}$ & $\begin{array}{l}\text { Jin et al., } 2012 \\
\text { [43] }\end{array}$ \\
\hline \multirow[t]{2}{*}{ Pig } & $\begin{array}{l}\text { 3' digital gene expres- } \\
\text { sion tag profiling }\end{array}$ & 1596 DE genes (with 887 up-regulated and 709 down-regulated) & $\begin{array}{l}\text { Li et al., } 2011 \\
{[45]}\end{array}$ \\
\hline & $\begin{array}{l}\text { RNA-Seq and Ge- } \\
\text { nome-wide association } \\
\text { studies }\end{array}$ & Insulin-like growth factor 2 (IGF2) & $\begin{array}{l}\text { Chen et al., } 2011 \\
\text { [44] }\end{array}$ \\
\hline
\end{tabular}


Further studies have also identified the molecular signatures of PPARY binding using ChIP-Seq [53-56]. Transcription factor 7-like 1 (TCF7L1) was found to repress a large number of cytostructural genes before adipocyte gene induction using ChIP-Seq [57]. The first genome-wide profile of H3K56 (lysine 56 of histone H3) acetylation, and binding location analysis of E2F4, C/EBPa and HSF-1 binding in human adipocytes derived from mesenchymal stem cells found that almost half of the genome shows signs of H3K56 acetylation. This acetylation is associated with transcription factors and proteins in the adipokine signaling, and will serve as an important resource to further understanding of adipocyte transcriptional regulation and epigenetic modifications [58].

Recent studies used DNase I Hypersensitive (DHS) site analysis in combination with deep sequencing, to detect dynamic changes of the chromatin landscape during adipocyte differentiation, coinciding with cooperative binding of multiple transcription factors to transcription factor hotspots $[59,60]$. In DHS site analysis, nuclear or whole-cell extracts containing proteins of interest are allowed to bind to DNA segments followed by the treatment of the resulting complexes with DNase I. Deep sequencing of the DNA released from DHS sites helps in the identification of regulatory elements for a given locus and to characterize chromatin structures [61]. The time-resolved expression profiling of all nuclear receptor superfamily members, using the chromatin-region specific primers by qRT-PCR of ChIP templates revealed that glucocorticoid receptor and its ligand cortisol as central regulatory factors controlling early regulatory events in human adipogenesis [62]. The combination of ChIP for enrichment of both coding and unexplored regulatory regions of transcriptional factors, coupled to the targeted re-sequencing or transcriptome analysis using RNA-Seq on next generation sequencing platforms, will provide further insights into the genomic architecture of its regulatory regions and the associated changes in transcriptomes. RNAseq will further prove to be effective in identifying transcriptomes under multiple conditions of adipogenesis and their response to various environmental factors.

\section{MicroRNA profiling}

MicroRNAs are non-coding small RNAs with approximately 22 nucleotides that participate in several biological processes, such as development, cell differentiation, apoptosis, metabolism and pathogenesis through the gene expression regulation mainly by mRNA translation repression [63-65]. Several mi-
croRNAs are reported to play a role in the physiology and pathology of adipose tissue of mammals $[66,67]$. Therefore, there is a great interest to characterize the microRNA expression profile in fat tissues of humans as well as farm animals in order to understand how microRNAs participate in the regulation of adipose tissue development. Recent studies reported the miRNA profiles in adipose tissue of meat farm animal, such as beef cattle [68,69] and pigs [70]. Adipose tissue (subcutaneous fat) from beef cattle showed different profiles of miRNAs according to the location in the fat depot, with 80, 66 and 63 miRNAs detected respectively in abdominal subcutaneous, back subcutaneous and rump subcutaneous tissues by qRT-PCR [68]. Besides not only depot location, but also the fat traits of the animals (high backfat thickness vs. low backfat thickness) impacts miRNA profiles found by qRT-PCR analysis. A total of $42 \mathrm{miR}-$ NAs were differentially expressed between these groups, being miR-378 the most differentially expressed. $\mathrm{Li}$ et al. [71] profiled swine adipose tissue (backfat) using a Solexa deep sequencing approach which allowed the identification of the sequence and relative expression of 227 miRNAs. Their results also showed that the abundant miRNAs belonged mainly to 32 miRNA gene families, which included miR-143, miR-103, let-7, and miR-148. Comparing the conserved miRNAs between the profiles of 7day old and 240 day old pigs, the authors found a total of 93 miRNAs up-regulated and 33 down-regulated in adult animals, indicating the impact of animal development in miRNA profiles of adipose tissue. Deep sequencing analysis also provided a global view of the complexity of the miRNA transcriptome and in total 164 potential novel tissue-specific miRNAs were detected [44].

\section{Future perspectives}

Understanding the molecular basis of adipogenesis and fat cell development is essential to identify new biomarkers. Adipogenesis is a complex process that appears to be regulated in a coordinated manner by genes, proteins, microRNAs expression to modulate fat formation in mammalian species. Integrated analysis of transcriptome, proteome, microRNAome and genome wide association studies are necessary to achieve the comprehensive view of the regulatory mechanisms on adipogenesis. Furthermore, detailed information on epigenetic regulation will be extremely beneficial to complement these studies to improve our understanding of the complexities of adipogenesis. 


\section{Conflict of Interest}

The authors have declared that no conflict of interest exists.

\section{References}

1. Large V, Peroni O, Letexier D, Ray H, Beylot M. Metabolism of lipids in human white adipocyte. Diabetes \& Metabolism. 2004; 30:294-309.

2. Galic S, Oakhill JS, Steinberg GR. Adipose tissue as an endocrine organ. Molecular and Cellular Endocrinology. 2010; 316:129-139.

3. German AJ, Ryan VH, German AC, Wood IS, Trayhurn P. Obesity, its associated disorders and the role of inflammatory adipokines in companion animals. The Veterinary Journal. 2010; 185:4-9.

4. Basu U, Guan LL, Taniguchi M, Zhao Y, Dodson MV. Application of 'omics' technologies on improvement of meat quality. In: Haugen S and Meijer S, ed. Nutritional biochemistry: Genomics, metabolomics and food supply. Hauppauge, NY: Nova Science Publishers; 2009:165-194.

5. Hausman GJ, Dodson MV, Ajuwon K, Azain M, Barnes KM, Guan LL et al. Board-invited review: the biology and regulation of preadipocytes and adipocytes in meat animals. Journal of Animal Science. 2009; 87:1218-1246.

6. Poulos SP, Hausman DB, Hausman GJ. The development and endocrine functions of adipose tissue. Molecular and Cellular Endocrinology. 2010; 323:20-34.

7. Lefterova MI, Lazar MA. New developments in adipogenesis. Trends in Endocrinology and Metabolism. 2009; 20:107-114.

8. White UA, Stephens JM. Transcriptional factors that promote formation of white adipose tissue. Molecular and Cellular Endocrinology. 2010; 318:10-14.

9. Nakachi Y, Yagi K, Nikaido I, Bono H, Tonouchi M, Schonbach $C$ et al. Identification of novel PPAR gamma target genes by integrated analysis of ChiP-on-chip and microarray expression data during adipocyte differentiation. Biochemical and Biophysical Research Communications. 2001; 372:362-366.

10. Prokesch A, Hacki H, Hakim-Weber R, Bornstein SR, Trajanoski Z. Novel insights into adipogenesis from omics data. Current Medicinal Chemistry. 2009; 16:2952-2964.

11. Costa V, Gallo MA, Letizia F, Aprile M, Casamassimi A, Ciccodicola A. PPARG: Gene expression regulation and next-generation sequencing for unsolved issues. PPAR Research. 2010; doi:10.1155/2010/409168.

12. Stoughton RB. Applications of DNA microarrays in biology. Annual Review of Biochemistry. 2005; 74:53-82.

13. Morey JS, Ryan JC, Van Dolah FM. Microarray validation: factors influencing correlation between oligonucleotide microarray and real-time PCR. Biological Procedures Online. 2006; 8:175-193.

14. Ross SE, Erickson RL, Gerin I, DeRose PM, Bajnok L, Longo KA et al. Microarray analyses during adipogenesis: understanding the effects of Wnt signaling on adipogenesis and the roles of liver $\mathrm{X}$ receptor alpha in adipocyte metabolism. Molecular Cellular Biology. 2002; 22:5989-5999.

15. Burton GR, Nagarajan R, Peterson CA, McGehee RE. Microarray analysis of differentiation-specific gene expression during 3T3-L1 adipogenesis. Gene. 2004; 329:167-185.

16. Liu J, DeYoung SM, Zhang M, Zhang M, Cheng A, Saltiel AR. Changes in integrin expression during adipocyte differentiation. Cell Metabolism. 2005; 2:165-177.

17. Pantoja C, Huff JT, Yamamoto KR. Glucocorticoid signaling defines a novel commitment state during adipogenesis in vitro. Molecular Biology of the Cell. 2008; 19:4032-4041.
18. Birsoy K, Berry R, Wang T, Ceyhan O, Tavazoie S, Friedman JM et al. Analysis of gene networks in white adipose tissue development reveals a role for ETS2 in adipogenesis. Development. 2011; 138:4709-4719.

19. Nakamura T, Shiojima S, Hirai $Y$, Iwama T, Tsuruzoe N, Hirasawa $\mathrm{A}$ et al. Temporal gene expression changes during adipogenesis in human mesenchymal stem cells. Biochemical and Biophysical Research Communications. 2003; 303:306-312.

20. Hung SC, Chang CF, Ma HL, Chen TH, Low-Tone HL. Gene expression profiles of early adipogenesis in human mesenchymal stem cells. Gene. 2004; 340:141-150.

21. Sekiya I, Larson BL, Vuoristo JT, Cui JG, Prockop DJ. Adipogenic differentiation of human adult stem cells from bone marrow stroma (MSCs). Journal of Bone and Mineral Research. 2004; 19:256-264.

22. Scheideler M, Elabd C, Zargossi LE, Chielini C, Hackl H, Sanchez-Cabo F. Comparative transcriptomics of human multipotent stem cells during adipogenesis and osteoblastogenesis. BMC Genomics. 2008; 9:340.

23. Rodriguez-Acebes S, Palacios N, Botell-Carretero JI, Olea N, Crespo L, Permingo R et al. Gene expression profiling of subcutaneous adipose tissue in morbid obesity using a focused microarray: distinct expression of cell cycle- and differentiation-related genes. BMC Medical Genomics. 2010; 3:61.

24. Tan SH, Reverter A, Wang Y, Byrne KA, McWilliam SM, Lehnert SA. Gene expression profiling of bovine in vitro adipogenesis using a cDNA microarray. Functional integrative genomics. 2006; 6:235-249.

25. Taniguchi M, Guan LL, Zhang B, Dodson MV, Okine E, Moore SS. Adipogenesis of bovine perimuscular preadipocytes. Biochemical Biophysical Research Communications. 2008; 366:54-59.

26. Taniguchi M, Guan LL, Zhang B, Dodson MV, Okine E, Moore SS. Gene expression patterns of bovine perimuscular preadipocytes during adipogenesis. Biochemical Biophysical Research Communications. 2008; 366:346-351.

27. Lee SH, Gondro S, Werf JV, Kim NK, Lim DJ, Park EW et al. Use of a bovine genome array to identify new biological pathways for beef marbling in Hanwoo (Korean Cattle). BMC Genomics. 2010; 11:623.

28. Guo H, Wang SH, Cao HJ, Xu K, Zhang J, Du ZL et al. Gene Microarray Analysis for Porcine Adipose Tissue: Comparison of Gene Expression between Chinese Xiang Pig and Large White. Journal of Animal Science. 2008; 21:11-18.

29. Barb CR, Hausman GJ, Lents CA, Lkhagvadorj S, Qu L, Cai W et al. Gene expression in hypothalamus, liver and adipose tissues and food intake response to melanocortin-4 receptor (MC4R) agonist in pigs expressing MC4R mutations. Physiological Genomics. 2010; 41:254-268.

30. Hausman GJ, Barb CR, Dean RG. Gene expression profiling in developing pig adipose tissue: non-secreted regulatory proteins. Animal. 2011; 5:1071-1081.

31. Rosen ED, MacDougald OA. Adipocyte differentiation from the inside out. Nature Reviews Molecular Cell Biology. 2006; 7:885-896

32. Timmons JA, Wennmalm K, Larsson O, Walden TB, Lass-mann $\mathrm{T}$, Petrovic $\mathrm{N}$ et al. Myogenic gene expression signature establishes that brown and white adipocytes originate from distinct cell lineages. Proceedings of the National Academy of Science (USA). 2007; 104:4401-4406.

33. Cristancho AG, Lazar MA. Forming functional fat: a growing understanding of adipocyte differentiation. Nature Reviews Molecular Cell Biology. 2010; 12:772-734.

34. Mathur SK, Jain P, Mathur P. Microarray evidences the role of pathologic adipose tissue in insulin resistance and their clinical implications. Journal of Obesity. 2011; doi: $10.1155 / 2011 / 587495$ 
35. Farmer SR. Transcriptional control of adipocyte formation. Cell Metabolism. 2006; 4:263-273.

36. Chen Z, Torrens JI, Anand A, Spiegelman BM, Friedman M. Krox20 stimulates adipogenesis via $C / E B P \beta$-dependent and -independent mechanisms. Cell Metabolism. 2005; 1:93-106.

37. Billon N, Kolde R, Reimand J, Monterio MC, Kull M, Peterson $\mathrm{H}$ et al. Comprehensive transcriptome analysis of mouse embryonic stem cell adipogenesis unravels new processes of adipocyte development. Genome Biology. 2010; 11:R80.

38. Puri V, Virbasius JV, Guilherme A, Czech MP. RNAi screens reveal novel metabolic regulators: RIP140, MAP4k4 and the lipid droplet associated fat specific protein (FSP) 27. Acta Phyiologica. 2008; 192:103-115.

39. Wang, Z, Gerstein M, Snyder M. RNA-seq: a revolutionary tool for transcriptomics. Nature Reviews Genetics. 2009; 10:57-63.

40. Metzker ML. Sequencing technologies - the next generation. Nature Reviews Genetics. 2010; 11:31-46.

41. Martin JA, Wang Z. Next-generation transcriptome assembly. Nature Reviews Genetics. 2011; 12:671-682.

42. Mizoguchi $Y$, Hirano $T$, Itoh $T$, Aso $H$, Takasuga A, Sugimoto $Y$ et al. Differentially expressed genes during bovine intramuscular adipocyte differentiation profiled by serial analysis of gene expression. Animal Genetics. 2010; 41:436-441.

43. Jin W, Olson NE, Moore SS, Basarab JA, Basu U, Guan LL. Transcriptome analysis of subcutaneous adipose tissues in beef cattle using 3' digital gene expression-tag profiling. Journal of Animal Science. 2012; 90:171-183.

44. Chen C, Ai H, Ren J, Li W, Li Pinghua, Qiao R et al. A global view of porcine transcriptome in three tissues from a full-sib pair with extreme phenotypes in growth and fat deposition by paired-end RNA sequencing. BMC Genomics. 2011; 12:448.

45. Li XJ, Yang H, Li GX, Zhang GH, Cheng J, Guan H et al. Transcriptome profile analysis of porcine adipose tissue by high-throughput sequencing. Animal Genetics. 2012 Apr;43(2):144-52.

46. Das PM, Ramachandran K, vanWert J, Singal R. Chromatin immunoprecipitation assay. Biotechniques. 2004; 37:961-969.

47. Ho JWK, Bishop E, Karchenko PV, Nègre N, White KP, Park PJ. ChIP-chip versus ChIP-seq: Lessons for experimental design and data analysis. BMC Genomics. 2011; 12:134.

48. Lefterova MI, Zhang Y, Steger DJ, Schupp M, Schug J, Cristancho A et al. PPARgamma and C/EBP factors orchestrate adipocyte biology via adjacent binding on a genome-wide scale. Genes Development. 2008; 22: 2941-2952.

49. Farnham PJ. Insights from genomic profiling of transcription factors. Nature Reviews Genetics. 2009; 10:605-616.

50. Nielsen R, Pedersen TA, Hagenbeek D, Moulos P, Siersbæk R, Megens $E$ et al. Genome-wide profiling of PPARgamma: RXR and RNA polymerase II occupancy reveals temporal activation of distinct metabolic pathways and changes in RXR dimer composition during adipogenesis. Genes and Development. 2008; 22:2953-2967.

51. Hamza MS, Pott S, Vega VB, Thomsen JS, Kandhadayar GS, Ng PW et al. De-novo identification of PPARgamma/RXR binding sites and direct targets during adipogenesis. PLoS One. 2009; 4:e4907.

52. Siersbaek R, Nielsen R, Mandrup S. PPARgamma in adipocyte differentiation and metabolism-novel insights from genome-wide studies. FEBS Letters. 2010; 584:3242-3249.

53. Wakabayashi KI, Okamura M, Tsutsumi S, Nishikawa N, Tanaka T, Sakakibara I et al. PPAR \{gamma\}/RXR\{alpha\} heterodimer targets gene of histone modification enzyme PR-Set7/Setd8 and regulates adipogenesis through a positive feedback loop. Molecular Cellular Biology. 2009; 29:3544-3555.

54. Lefterova MI, Steger DJ, Zhuo D, Qatanani M, Mullican SE, Tuteja $\mathrm{G}$ et al. Cell-specific determinants of peroxisome prolif- erator-activated receptor gamma function in adipocytes and macrophages. Molecular Cellular Biology. 2010; 30:2078-2089.

55. Mikkelsen TS, Xu Z, Zhang X, Wang L, Gimble JM, Lander ES et al. Comparative epigenomic analysis of murine and human adipogenesis. Cell. 2010; 143:156-169.

56. Schmidt SF, Jørgensen M, Chen Y, Nielsen R, Sandelin A, Mandrup S. Cross species comparison of C/EBPa and PPARg profiles in mouse and human adipocytes reveals interdependent retention of binding sites. BMC Genomics. 2011; 12:152.

57. Cristancho AG, Schupp M, Lefterova MI, Cao S, Cohen DM, Chen CS et al. Repressor transcription factor 7-like 1 promotes adipogenic competency in precursor cells. Proceedings of the National Academy of Science (USA). 2011; 39:16271-16276.

58. Lo KA, Bauchmann MK, Baumann AP, Donahue CJ, Thiede MA, Hayes LS et al. Genome-Wide Profiling of H3K56 Acetylation and Transcription Factor Binding Sites in Human Adipocytes. PLoS ONE. 2011; 6:e19778.

59. Siersbaek R, Nielsen R, John S, Sung MH, Baek S, Loft A et al. Extensive chromatin remodelling and establishment of transcription factor 'hotspots' during early adipogenesis. The EMBO Journal. 2011; 30:1459-1472.

60. Steger DJ, Lazar MA. Adipogenic hotspots: where the action is. The EMBO Journal. 2011; 30:1418-1419.

61. Hager G. Footprints by deep sequencing. Nature Methods. 2009; 6:254-255.

62. Lahnalampi M, Heinaniemi M, Sinkkonen L, Wabistch M, Carlbert C. Time resolved expression profiling of the nuclear receptor superfamily in human adipogenesis. PLoS ONE. 2010; 5:e12991.

63. Krützfeldt J, Stoffel M. MicroRNAs: A new class of regulatory genes affecting metabolism. Cell Metabolism. 2006; 4:9-12.

64. Lee CT, Risom T, Strauss WM. MicroRNAs in mammalian development. Birth Defects Res C Embryo Today. 2006; 78:129-39.

65. Williams A. Functional aspects of animal microRNAs. Cell Molecular Life Science. 2008; 65:545-62.

66. Romao JM, Jin W, Dodson MV, Hausman GJ, Moore SS, Guan LL. Microrna regulation in mammalian adipogenesis. Experimental Biology and Medicine 2011 236:997-1004.

67. Xie H, Sun L, Lodish HF. Targeting micrornas in obesity. Expert Opinion on Therapeutic Targets. 2009; 13:1227-1238.

68. Jin W, Grant J, Stothard P, Moore S, Guan L. Characterization of bovine miRNAs by sequencing and bioinformatics analysis. BMC Molecular Biology. 2009; 10:90.

69. Jin W, Dodson M, Moore S, Basarab J, Guan LL. Characterizati on of microRNA expression in bovine adipose tissues: a potential regulatory mechanism of subcutaneous adipose tissue development. BMC Molecular Biology. 2010; 11:29.

70. Cho I, Kim J, Seo H, Lim D, Hong J, Park Y et al. Cloning and characterization of microRNAs from porcine skeletal muscle and adipose tissue. Molecular Biology Reports. 2010; 37:3567-3574.

71. Li G, Li Y, Li X, Ning X, Li M, Yang G. MicroRNA identity and abundance in developing swine adipose tissue as determined by solexa sequencing. Journal of Cellular Biochemistry. 2011; 112:1318-1328. 